\title{
Online literary creativity of digital natives: genre and thematic analysis
}

\author{
Leila Algavi ${ }^{1}$, Irina Volkova $^{2, *}$, Shuanat Kadyrova ${ }^{1}$, and Natalya Rastorgueva ${ }^{1}$ \\ ${ }^{1}$ RUDN University, Theory and History of Journalism Department, 117198 Moscow, Russia \\ ${ }^{2}$ RUDN University, Mass Communication Department, 117198 Moscow, Russia
}

\begin{abstract}
The article presents the results of a genre-thematic analysis of 1129 texts recognized as the most popular in 2019 on the platform Ficbook.net. It was found that young people of generation $\mathrm{Z}$ - the authors of these works (prose, poetry, journalism), were broadcasting existential anxiety and depression, tell stories which content is mainly related to violence and sex. The research is innovative in connection with empirical material that has not been studied before in the context of the problems of socialization of the digital generation. The features of socialization and motivation of "digital natives" representatives, their behavior in social networks and in real life are revealed. The results obtained can be useful for specialists in media communications, as well as psychologists, sociologists and teachers.
\end{abstract}

\section{Introduction}

The idea of this article came to its authors in connection with the TV show "Let them Talk" study (see: Algavi, Volkova, Kadyrova, Rastorgueva, 2018). Then the results of quantitative and qualitative analysis showed that the main topic of conversation, and probably the meaning of life of most of the participants and experts of the show was the possession of a child as a key to well-being. Child in virtually all TV-issues is a sort of "macguffin", a plot-forming object, "it doesn't matter what kind of thing it is; the main point is that everyone wants to obtain it". With a few exceptions, both participants and experts of "Let them Talk" TV show represent the generation of the "pre-Internet era witnesses" or generation X, according to the theory of W. Strauss and N. Howe (1991). Researchers of generational values (Alpatova, Semenikhina, 2011; Astashova, 2014; Radayev, 2018; Shamis, Nikonov, 2016, etc.) indicate the period of birth of "Xs" from 1960 to 1984. "Xs" survived the Afghan War, Chernobyl atomic power station accident, the AIDS epidemic, the collapse of the USSR, the crisis of the 1990s, and the painful breakdown of cultural and moral guidelines and values. These people are focused on the result, while it is not so important for them how it is achieved, and the main values for them are freedom, lack of constant control (Chernikov, 2014: 156), individualism, self-hope, the desire for choice (Volkova, 2013), readiness for change (Ozhiganova, 2015: 96).

\footnotetext{
* Corresponding author: volkova-ii@rudn.ru
} 
Before the eyes of this generation, technology has changed many times: first, cable and satellite television entered their lives, after that - personal computers and computer networks, followed by mobile phones and the Internet of Things. And as you know, "technological innovations have long been known as factors of generation change" (Tulgan, 2009: 6). Moreover, each next generation differs from the previous one in habits, character, values and goals.

We decided to take a closer look at those McGuffin children whom their fathers and grandfathers, mothers and grandmothers are fighting for on the air. That is, to look at the generation of "digital natives" - people born in new socio-political conditions, whose period of growing up fell on the new millennium, 1999-2016 (Radayev, 2018). These are people who were "born with a button on their finger", their heuristic and creative abilities are redirected to the virtual area where online is the basie state. Their main goal is to become happy. This can only be achieved if you find your way. This is done through selfdevelopment, self-improvement, self-realization, which means "any hobby, any activity "at will": travelling, music or drawing, going to the cinema or theater, interest in history or photography". (2) It is logical that the artifacts of this self-realization should be searched on the Internet.

\section{Materials and Methods}

In order to understand how the "digital natives" - the McGuffins - see the world and present a part of this world to representatives of the non-digital generation of parents - "digital immigrants", - we decided to analyze the works (texts) posted on the platform Ficbook.net ("The Book of Fan Fiction", hereinafter referred to as BFF).

The authors of this article proceeded from the fact that every literary text, regardless of its quality, reflects the author's worldview, his world outlook, and, in particular, his ideas about the laws that govern this world and that govern people.

The BFF resource was created in 2007 for fans of movies, TV series, and books. They publish here their stories and fanfics. using characters, storylines, as well as the art world and other elements of their favourite works.

Ficbook.net - is a Russian-language alternative to the international archive of fan literature that has existed since 1998 and is known as Fanfiction.net.

Statistical monitoring of the BFF platform with the help of the Similar Web analytical service shows that the target site with which Ficbook.net is connected by the highest conversion (in other words, the largest number of users' "clicks") is the social network VKontakte (VK). It has the widest coverage in Russia with 97 million active users per month. Rusability analysts give the following characteristics of the VK user audience: "The maximum level of engagement is observed in the 18-24 age group - almost every day $91 \%$ of respondents use social networks. In the category of 25-34 the percentage is 69\%".

On the BFF, users post their works free of charge. The domestic platform, in addition to fan fiction, allows you to publish so called "originals" - original pieces of prose, poetry and journalism.

Russian and foreign researchers study the features of fan creativity (see: Algavi, Kharchenko, 2020) on the material of fan fiction and in the context of audience activity, collective meaning formation, and ways of expressing interpretations of the original media source. This article examines the texts of originals.

The choice of originals as an empirical material is explained by the following reasons. First, unlike fan fiction, the authors of originals are not associated with the fan community of any particular film (TV series)/ That is why it is not necessary for them to adhere to the plot regulations and restrictions. Secondly, the authors are free to express themselves, they 
are free to construct any worlds they want, even if they do not meet the expectations of their subscribers.

We analyzed 1129 original works that were included in the TOP of the BFF archive in August 2019 in terms of the number of awards from readers, comments and "likes". The first criterion (readers' award) was a priority for us. The "like" mark does not require any effort from the reader. And as for comments, even monosyllabic responses of the author are taken into consideration while counting them. Which means that there is a kind of a "cheat" of the responses' total number. The award, in addition to time and effort, requires money from the reader. So it is the awards, according to the authors, that are the measure of the reader's interest in fan fiction on the BFF: the audience votes in rubles. The empirical material processed for this study is available in the open access.

\section{Results and Discussion}

It should be noted at once that the understanding of genres in BFF differs from the classic definition given by R. Wellek and O. Warren. According to them, a genre can be conditionally considered a group of literary works in which a common "external" (size, structure) and "internal" (mood, attitude, intention, in other words — theme and audience) form is theoretically revealed (Wellek, Warren, 1956).

On the BFF, neither the poetic size nor the structure itself does not matter when referring a work to a particular genre: only the plot, or rather the nature of relationship between the characters is the thing that realy matters. And it is the latter that particularly attracts the public.

Of the 1,129 works in the August list of popular originals, $83 \%$ belong to the "slash" category, which, together with fan fiction in the "femslash" and "mixed" categories, is $87 \%$ (see Table 1). One should pay attention to the rating (warning marks accepted among fikraters that restrict viewing).): $89 \%$ of all works have got rating from $\mathrm{R}$ (presence of sex and violence, obscene language) to $\mathrm{NC}-21$ (description of sex and violence).

Table 1. Distribution of popular originals (2019) by genre.

\begin{tabular}{|c|c|c|c|}
\hline Focus & Description & Quantity & $\%$ \\
\hline gen & $\begin{array}{l}\text { sexual relationships are not } \\
\text { described or mentioned, they } \\
\text { do not play a decisive role }\end{array}$ & 4 & 48 \\
\hline get & $\begin{array}{l}\text { romantic and / or sexual } \\
\text { relations between a man and a } \\
\text { woman }\end{array}$ & 100 & 9 \\
\hline slash & $\begin{array}{l}\text { romantic and / or sexual } \\
\text { relations between men }\end{array}$ & 933 & 83 \\
\hline femslash & $\begin{array}{l}\text { romantic and/or sexual } \\
\text { relations between women }\end{array}$ & 12 & 1 \\
\hline mixed & $\begin{array}{l}\text { several equivalent romantic } \\
\text { lines (get, slash, femslash) }\end{array}$ & 33 & 3 \\
\hline other & $\begin{array}{c}\text { a journalistic text about } \\
\text { fandom or writing based on } \\
\text { the structure: "thesis, } \\
\text { arguments in its favour, } \\
\text { conclusion" }\end{array}$ & 4 & 0 \\
\hline
\end{tabular}

There are many subgenre categories within the five directions (sometimes called «genres» by the fiction writers) shown in the table above. The grounds for classification are 
diverse: content, which includes the time and place of the action, the features of the relationship between the characters, the character of the narrator himself. In separate groups, there are works that describe the events and situations of the daily life of the characters — "everyday life"; stories about educational institutions, their employees and students - "educational institutions". The authors of novels and poems in the subgenre "love / hate" describe the relationship of characters who adore and hate each other at the same time, and if they are initially in a romantic and/or sexual relationship — this is already "ER" (from the English expression "established relationship»). Works written in the first person are marked "POV" (from the English expression "point of view"), etc.

All the so called genres can be divided into three groups: the inner life of the character, the relationship of the characters, the interaction of the character with the outside world. In general, the array of texts considered by us allows us to conclude that all three categories are represented evenly. However, if we narrow down the sample to the first hundred popular originals, it turns out that the most popular of them belong to the first two groups, i.e. works that focus on the inner world of the hero, on his experiences or on romantic relationships between the characters. We are particularly interested in the third category of genres, sociocentric (the interaction of the character with the outside world), which most clearly shows how the digital generation imagine the modern world. A selection of the top ten, most popular, originals demonstrates a commitment to sociocentric narratives, while the young public prefers works that are dominated by negative emotions and experiences. 9 out of 10 fanfics are written in the "angst" genre (depressive motives, focus on physical, and, more often, spiritual suffering of the characters). 5 out of 10 fanfics belong to the genre of "drama" (conflicts of the characters with themselves, society or with each other). Another 5 fanfics belong to the genre of "psychology", where psychological problems are described in detail, and reflections on the causes and motives of actions are given. Another 4 belong to the genre of "hurt/comfort" - a story about emotional and/or physical suffering of the characters, about how others take care about them. All this is diluted with romance $(5 / 10)$ and humor $(5 / 10)$, but overall, the picture is very depressing. The genres formed and accepted by the users of the BFF platform (names and descriptions in the form used by the fiction writers) are shown in the table 2.

Table 2. Fanfiction genres, as described by the fiction writers.

\begin{tabular}{|c|c|c|c|}
\hline Genres & Description & Quantity & $\%$ \\
\hline $\begin{array}{c}\text { everyday } \\
\text { life }\end{array}$ & situations from the daily lives of the characters & 490 \\
\hline $\begin{array}{c}\text { omegavers } \\
\text { the action takes place in a world where the characters are divided into } \\
\text { three types: alpha, beta and omega, each of which has a number of } \\
\text { physiological characteristics, sexual preferences, a certain position in the } \\
\text { social hierarchy. }\end{array}$ & 342 & 30 \\
\hline $\begin{array}{c}\text { educational } \\
\text { institutions }\end{array}$ & $\begin{array}{c}\text { the key role is played by employes of educational institutions and } \\
\text { students. }\end{array}$ & 236 & 21 \\
\hline $\begin{array}{c}\text { fantasy } \\
\text { mythical } \\
\text { creatures }\end{array}$ & $\begin{array}{c}\text { fantasy and fairy tale motifs are used, events most often take place in a } \\
\text { fictional world, the characters encounter supernatural beings and }\end{array}$ & 234 & 21 \\
\hline $\begin{array}{c}\text { fantastic } \\
\text { phena, while miracles are the norm of the described world }\end{array}$ & $\begin{array}{c}\text { ne work is based on an element that does not occur or cannot exist in the } \\
\text { real world }\end{array}$ & 88 & 8 \\
\hline $\begin{array}{c}\text { popadants } \\
\text { aka } \\
\text { travellers }\end{array}$ & $\begin{array}{c}\text { it describes characters who somehow get into another world or move into } \\
\text { the body of an inhabitant of another world }\end{array}$ & 69 & 6
\end{tabular}


Table 2. Continued

\begin{tabular}{|c|c|c|c|}
\hline action & $\begin{array}{l}\text { the work is full of action, battles, chases, the emphasis is made on the } \\
\text { active actions of the characters }\end{array}$ & 61 & 5 \\
\hline mystics & $\begin{array}{c}\text { a significant role is played by phenomena whose reality cannot be proved } \\
\text { and justified from a scientific point of view }\end{array}$ & 45 & 4 \\
\hline detective & $\begin{array}{l}\text { the process of investigating a mysterious incident, most often of a criminal } \\
\text { nature, the main goal of the characters is to clarify the circumstances of the } \\
\text { event, solve the mystery and find the culprits }\end{array}$ & 28 & 2 \\
\hline $\begin{array}{l}\text { alternate } \\
\text { universe }\end{array}$ & $\begin{array}{l}\text { one or more elements of the canon are subject to change: this can be a } \\
\text { different world, a different historical period, the placement of characters in } \\
\text { circumstances unrelated to the canon, a partial or complete change in } \\
\text { canonical events }\end{array}$ & 26 & 2 \\
\hline dystopia & $\begin{array}{l}\text { the action takes place in a world where disregard for human rights has } \\
\text { reached its highest point, characteristic signs of dystopia: totalitarian } \\
\text { regimes, environmental and man-made disasters, the general decline of } \\
\text { society. }\end{array}$ & 11 & 1 \\
\hline $\begin{array}{l}\text { post- } \\
\text { apocalyptic }\end{array}$ & $\begin{array}{l}\text { it describes a world where a certain catastrophe occurred, which put the } \\
\text { population on the verge of extinction or in very difficult conditions for } \\
\text { survival }\end{array}$ & 9 & 1 \\
\hline horrors & $\begin{array}{l}\text { the game is based on the unknown, created at the expense of the dangers } \\
\text { encountered on the characters way }\end{array}$ & 8 & 1 \\
\hline $\begin{array}{l}\text { historical } \\
\text { epochs }\end{array}$ & $\begin{array}{l}\text { the action takes place in a certain historical period in the appropriate } \\
\text { entourage, the narrative tends to reflect real historical events }\end{array}$ & 6 & 1 \\
\hline
\end{tabular}

As can be seen from the table 2, we are dealing with a place of action (space) and an entourage (or setting), while the content of most works is romance novels. Works with similar characteristics (often with other genre designations) have long been familiar to readers, with the exception of the relatively new, but very popular direction "slash" (see Table 1) and its genre variety "omegavers". The last one appeared in 2010 in the fan community "Supernatural" in response to a request to write a fan fiction about the love relationship between actors Jared Padalecki (Jared Padalecki) and Jensen Ackles (Jensen Ackles), who play the main roles in the series "Supernatural (SN)". In this case, one of them had to be a male alpha, the second omega. Alpha differed from omega in some physiological features, which the author of the request learned from the anatomy of male individuals of the canine family. Wolves have hierarchical relationships in which alpha, omega, and beta are present. Alpha male, leader. In rare cases, it may be a female. Beta is his second-in-command. Omega is the most disenfranchised and lowest ranked wolf in the pack. To some extent, this structure of society resembles the system of subordinationdominance adopted in animal communities, in which everyone occupies a certain place, performs their functions. And the rights that a particular representative of the fictional world enjoys depend on his belonging to the "alphas" or "omegas".

The idea of transferring the physiologically predetermined hierarchy of animal dominance to human society appealed to fans: by 2013, Omegavers had moved beyond the SN fan community and gained popularity. Researchers have called it a "perfect collision" (Busse, 2013: 293). By 2015, Omegavers had become popular among original authors, and professional publishers began publishing novels in this genre. In 2018, a copyright lawsuit 
was initiated, in which two authors and two publishers opposed each other. The materials of the trial, known in the fan community as the Omegaverse Litigation, contain a legal description of the signs of "omegaverse".

In general, "omegavers" can be called an alternative universe, where there is a division into alphas, betas and omegas, the differences between which are manifested not at birth (as in class society), but during puberty. To some extent, the genre of homoerotic manga "BL" (from the English expression «boys love») can be considered a kind of forerunner of "omegavers".

In the behavior of the characters of the novels written in "slash" and "omegavers" genres the features of generation $\mathrm{Z}$ are clearly traced, highlighted by the chief researcher of the Research Institute of the Ministry of Internal Affairs of Russia, Professor I. Sundiev.:

- decreased libido, lack of pronounced interest in the opposite sex (of the 10 most popular works of 2019, only one is written in the genre of "get", all the others are "slash"; in the work "The Second Lady's Earring" father makes his eldest son to marry a man in order to fulfill the terms of a peace treaty);

- simplified view of reality (the hero of the original "Leave and Stay" chooses suicide, not coping with the difficulties of life);

- psychological lability, increased tendency to social deviations and aggression (for the heroes of almost all the works of the TOP 10, frequent use of obscene language is characteristic).

Google Data Science specialist. Steven-Davidowitz is confident that new data, which has become more accessible in the digital age, can radically expand our understanding of human nature, open up in the human community what was previously hidden. In other words, the trends in society that could not be detected by traditional methods became quite obvious after some people were able to post their creativity on the Internet in open access, and others-to consume it. In a world where the ideas of democracy are promoted, works whose characters strive to live in a hierarchical society have appeared and quickly gained popularity among young people. While adults argued for the possession of children as a certain value, the children grew up and created their own world, little understood by the idealized representatives of the older generation.

Parents in the works we have studied often appear as champions of conventions, usurped power cynics who seek to command their own children. Children, in most cases, agree to the established rules, giving their future to the will of chance ("Two in a boat, not counting the contract"), or make a decision that may shock their parents ("Heard in the second life"). Nevertheless, a rare work does not end with a happy ending: the hero adapts to the conditions, finds positive moments in the situation in which he finds himself and, in the end, finds harmony and well-being. In this, he is helped by another main character, who, in the image of a "prince on a white horse", saves a young man in trouble in time, giving him peace of mind and confidence in the future. Thus, from one relationship of" submission - dominance", the hero falls into others, which, this time, bring him satisfaction.

It is interesting that, according to the Russian thinker N. K. Mikhailovsky, just " the appearance of a clear complex hierarchy in society constrains the individual. A person loses his independence, he is forced to fulfill his narrow role within the social organism. Constrained by their narrow obligations to society, a person loses the opportunity to expand the formula of their life, and, therefore, the opportunity to find personal happiness" (Vyazinkin, 2012: 290). Thus, we see that the concept of personal happiness in the twentyfirst century has undergone changes. For today's youth, it consists in peace and comfort, in enjoying life.

Returning to the works of V. Strauss and N. Howe, we note that the cycle of generational change described by them (approximately 80 years) It is clearly shown in the 
comparison of the "digital aborigines" and the "silent generation" (1925-1942). Both were formed not on the actual events experienced, but on their interpretations (Miroshkina, 2014: 55-56). And if the first (they are called " scribes») they tried to isolate themselves from the external environment by immersing themselves in reading adventure literature, while the latter forms an alternative virtual world from works written by themselves.

\section{Conclusion}

So, the analysis of 1129 original works revealed the genre preferences of the Ficbook.net. young audience. We come to the conclusion that the greatest interest among fans is caused by sex and violence. The authors of the works are mainly girls who make the main characters of the male sex. The most popular works convey strong emotional experiences, namely a sense of existential anxiety and depression.

Psychologists, sociologists, and educators should think about the causes of this condition. For experts in the field of mass communications, it is important to note that Internet technologies are contributing to the rapid spread of new forms of storytelling around the world, as happened with the genre of "slash". Young amateur writers, representatives of the digital generation, create works that are an important source for identifying the features of their socialization and motivation, behaviour in social networks and in real life.

Generation Z, outwardly demonstrating agreement with the existing conditions, without openly rebelling against the established orders, eventually acts as it considers convenient for itself. The views, interests and values of modern youth have recently undergone significant changes, and studying them on the basis of Internet sources, such as the "Book of Fan Fiction" with a multi-million audience, is the most important condition for the harmonization of the digital society.

\section{References}

1. L. O. Algavi, A. V. Harchenko, RUDN Journal of Studies in Literature and Journalism, 25(3), 531 (2020)

2. D. O. Algavi, I. I. Volkova, Sh. N. Kadyrova, N. E. Rastorgueva, RUDN Journal of Studies in Literature and Journalism, 23(4), 441 (2018)

3. K. A. Alpatova, T. A. Semenihina, Scientific problems of humanitarian research, 6, 238 (2011)

4. Ju. V. Astashova, Bulletin of the South Ural State University. Ser. "Economics and Management", 8(1), 108 (2014)

5. I. I. Volkova, Modern problems of science and education, 6 (2013) http://www.science-education.ru

6. D. M. V'jugina, Mediaskop, 4 (2017) http://www.mediascope.ru

7. A. Ju. Vjazinkin, Bulletin of the Tambov University. Series: Humanities, 108(4), 287 (2012)

8. M. R. Miroshkina, Education issues 2, 50 (2014)

9. E. M. Ozhiganova, Business education in the knowledge economy, 1(1), 94 (2015)

10. V. V. Radaev, Sociological research, 3, 15 (2018)

11. B. V. Chernikov, Bulletin of Tomsk State University, 386, 153 (2014)

12. E. Shamis, E. Nikonov, Theory of generations. Extraordinary X (2016) 
13. W. Strauss, N. Howe, Generations: The History of America's Future, 1584 (1991)

14. B. Tulgan, Not Everyone Gets A Trophy: How to Manage Generation Y (2009)

15. R. Wellek, A. Warren, Theory of Literature (1956) 